\title{
Financial Analysis of Keora (Sonneratia apetala) Plantations in Bangladesh
}

\author{
Sheikh Sirajul Islam ${ }^{1,2 *}$, Md. Abul Kalam Azad ${ }^{1}$, Jonaed Kabir ${ }^{1}$, Mohammed Abu Taher Hossain ${ }^{2}$ \\ ${ }^{1}$ Department of Business Administration, International Islamic University Chittagong, Bangladesh \\ ${ }^{2}$ Bangladesh Forest Research Institute, Chittagong, Bangladesh \\ Email: \{*ssislam, mjk.iiuc\}@yahoo.com, azadiiuc@gmail.com
}

Received September 13, 2011; revised October 15, 2011; accepted October 28, 2011

\begin{abstract}
An attempt has been taken to compare economic performance of different ages of keora (Sonneratia apetala) Plantations in coastal zone in this paper. The main objective was to find out financial rotation and profitability of keora plantation. The existing market price of round wood per cubic meter and fuel wood per ton were found to be Tk. 2650 to Tk. 3530 and Tk. 670 to Tk. 940 respectively near plantation area in 2003. The harvesting and processing costs were estimated as $20 \%$ and $10 \%$ of the standing value of the trees. The value of IRR and other economic determinants for timber were varied among Coastal Afforestation Divisions mainly due to different rates of siltation, salinity and other factors involved on the forest floor in coastal zone. However, applying the economic determinants throughout coastal zone, financially remarkable rotation age for timber was found to be within $14^{\text {th }}$ to $16^{\text {th }}$ year of plantation and rotation age for fuel wood as $9^{\text {th }}$ year of plantation. Applying the same economic determinants keora plantation was also found as profitable in coastal zone in Bangladesh.
\end{abstract}

Keywords: Keora; Plantation; Determinants; Profitable

\section{Introduction}

Keora is one of the main and pioneer planting species along the coastal belt of Bangladesh. Nowhere else in the world, mangrove plantation has been raised with such a large scale keora plantation along the coastal belt in Bangladesh [1]. The species is highly suitable in newly formed muddy land in coastal belt. The massive Afforestation programme was under taken along the coastal belt and offshore islands of Chittagong, Noakhali, Bhola, Barisal and Patuakhali. Coastal afforestation programme was first initiated along the coastal belt of Bangladesh in 1966 and it is still going on [2]. The spacings were applied from $(1.02 \mathrm{~m} \times 1.20 \mathrm{~m})$ to $(1.80 \mathrm{~m} \times 1.80 \mathrm{~m})$ where planted seedlings were 6945 to 3085 per hectare respectively. There were mono and mixed types of plantations in the coastal afforestation programme. The other species in the mixed plantation are kankra (Bruguiedoa Sexuangula), baen (Avicennia officinalis), gewa (Excecaria agallocha) etc. Though the initial year of plantation was 1966 but most of the successful plantations were found physically from 1980 .

The objective of starting coastal Afforestation programme in the country was primarily to stabilize accreted land and protecting destruction, losses of assets and lives in

\footnotetext{
"Corresponding author.
}

coastal areas against natural disasters like cyclone, tidal bore, etc. The secondary objective was to develop natural land management system and uplifting the socio-economic condition of the people through multiple benefits of forest resources in coastal areas. Timber and fuel wood production of the species, its use in different types of industries and creation of employment opportunities were also the ultimate objectives of the Forest Department [1]. So the production of the species recommends to make hardboard, pulpwood, packing boxes, bobbins, joinery, doors, windows, etc. Many plantations of the species of different areas have become older in coastal zone.

Unfortunately, a severe stem borer attack was first reported in keora plantations in all coastal areas [3]. Later on Bangladesh Forest Research Institute conducted a sample survey and the percentage of overall infestation was estimated at 59\% [4]. Infested trees were suggested to remove and mixed plantations of keora with acceptable species was recommended. Later on keora plantations were found successful in all coastal zones.

But no financial analysis was done for this valuable plantation. Determination of acceptable rotation age and profitability of this plantation is absolutely necessary. So, an attempt has been taken to find out financial rotation age and profitability of keora plantation in coastal zones through applying economic determinants. 


\section{Materials and Method}

A study was done on the financial analysis of keora plantations in three Coastal Plantation Divisions. A sampling design was prepared for almost all the Coastal Afforestation Divisions. The site of the survey was included the plantations from each Costal Afforestation Division established in Chittagong. Barisal and Patuakhali from 1980 to 1996 A samples of 3 plots from each plantation year and each plot size $(10 \mathrm{~m} \times 10 \mathrm{~m})$ of 0.01 ha was considered for the selected keora plantation of every Coastal Afforestation Division. Collection of data and analysis were performed separately for all administrative Coastal Afforestation Division except Noakhali due to unfavorable situation of institutional team work. The plantations were identified with the help of the local forest staff. The ages of the plantations were confirmed by consulting the plantation journals kept in the respective Forest Range Offices. Height and diameter at breast height (DBH) of the stands were measured from each selected plot by Haga Altimeter and Diameter tape respectively. Information regarding physical and financial (direct cost) aspects on keora plantation was collected from two different locations of each (coastal) division. Indirect cost including those of administration, supervision, etc. were not taken into account [5]. Data on the costs of the raising nursery plantations and other maintenance operations were collected from plantation journal of the local range office. The particular harvesting and processing costs were deducted in a certain percentage from standing value of the trees [6]. The mode of marketing and market price of sawn wood, round wood and fuel wood of keora was collected from the nearest local market of the study area. Existing market price was considered to evaluate the input costs and returns of the species. The cost of land and thinning were not considered because of ownership of Forest Department and no thinning opera- tion was done in the plantation.

The determinants are Net Present Value (NPV), Internal Rate of Return (IRR), Benefit Cost Ratio (B/C), Efficiency Index (EI), Land Expectation value (Le) and Equal Annual Equivalent (EAE) interms of the Le and NPV those were applied to find out the economically right rotation period and profitability of the species. The mathematical approach to the financial analysis of plantations depends on a certain interest rate on the following economic determinants.

1) $\operatorname{NPV}\left(\right.$ Net Present Value) $=\sum \frac{\mathrm{R}_{\mathrm{n}}}{(1+\mathrm{i})^{\mathrm{n}}}-\sum \frac{\mathrm{C}_{\mathrm{n}}}{(1+\mathrm{i})^{\mathrm{n}}}$

2) IRR (Internal Rate of Return) $=\sum \frac{\mathrm{R}_{\mathrm{n}}}{(1+\mathrm{i})}$

$$
-\sum \frac{C_{n}}{(1+i)^{n}}=0
$$

3) Benefit Cost Ratio (B/C) $=\frac{\sum \frac{\mathrm{R}_{n}}{(1+\mathrm{i})^{\mathrm{n}}}}{\sum \frac{\mathrm{C}_{\mathrm{n}}}{(1+\mathrm{i})^{\mathrm{n}}}}$

where,

$\mathrm{R}_{\mathrm{n}}=$ Returns at every n year

$\mathrm{C}_{\mathrm{n}}=$ Cost at every $\mathrm{n}$ year

$\mathrm{n}=$ Number of years

$\mathrm{i}=$ Interest Rate

$$
E A E=N P V\left[\frac{i(1+i)^{t}}{(1+i)^{t}-1}\right]
$$

where,

$\mathrm{EAE}=$ Equal Annual Equivalent

$\mathrm{NPV}=$ Net Present Value

$\mathrm{i}=$ Interest Rate

$\mathrm{t}=\operatorname{Rotation} \operatorname{Period}(1, \cdots, \mathrm{n})$

$$
\mathrm{Le}=\frac{\mathrm{Yr}+\mathrm{Tb}(1+\mathrm{i})^{\mathrm{r}-\mathrm{b}}+1\left[\frac{(1+\mathrm{i})^{\mathrm{r}}-1}{\mathrm{i}}\right]-C c(1+\mathrm{i})^{\mathrm{r}-C}-e(1+\mathrm{i})^{\mathrm{r}}-1}{(1+\mathrm{i})^{\mathrm{r}}-1}
$$

where,

$\mathrm{Y}=$ Net yield at rotation age

$\mathrm{T}=$ Net value of intermediate cuttings

$\mathrm{b}=$ Age at which revenue is received

$\mathrm{I}=$ Annual income

$\mathrm{C}=$ Net value of intermediate cost

$\mathrm{c}=$ Age at which cost is incurred

$\mathrm{e}=$ annual expenses

$\mathrm{r}=$ Rotation

$\mathrm{i}=$ Interest rate

Equation for estimating volume over bark (Vob) of three different coastal divisions [5].

$\mathrm{InVob}=-8.66152+1.58656 \times \mathrm{InD}+0.77152 \times \mathrm{InH}$ for Chittagong.

$$
\mathrm{InVob}=-9.23507+1.69673 \times \operatorname{InD}+0.92309 \times \operatorname{InH}
$$
for Barisal.

$$
\mathrm{InVob}=-8.75215+1.75034 \times \operatorname{InD}+0.64233 \times \mathrm{InH}
$$
for Patuakhali.

\section{Result and Discussion}

Raised plantations have tremendous contribution directly as tangible and intangible benefits in coastal areas. Intangible benefits are considered as protecting lives, properties environments and socio-cultural welfare of the people living in the coastal zone [7]. So it is very tough 
to quantify the value to benefits of protecting lives, assets and other uncountable welfare of population and contributions to acceleration of newly land formation and development of land suitable for agricultural activities. Therefore, no financial values were considered other than the fuel and timber yield per hectare of keora plantation [8]. Assessment relating to financial approach depending on market survey and estimated present stocking yield of standing trees per hectare were done in coastal zone in 2010. The average market prices of sawn wood, round wood and fuel wood were estimated to be Tk. $5093 / \mathrm{m}^{3}$, Tk. $3050 / \mathrm{m}^{3}$ and Tk. $30 / \mathrm{m}^{3}$ respectively. The values of round wood and fuel wood of market price were mainly considered for the study.

The maximum height and DBH were found in the plantation of the year 1980-1981 in Barisal and Patuakhali Coastal Afforestation Divisions [9] and lowest in the year 1989-1990 in Chittagong Coastal Afforestation Division (Table 1). Measurement of one to five feet bottom part of the trees was not possible due to sedimentation in forest floor of the plantation. Sedimentation rate was observed highest in areas of Chittagong Coastal Afforestation Division.

The maximum number of trees per hectare was found in the plantation of the year 1989-1990, 1990-1991 and 1995-1996 in Chittagong, Barisal and Patuakhali Coastal Division respectively. Highest yield was found in the year 1986-1987, 1983-1984 and 1980-1981 in these divisions became of size of the trees (Table 2). The elimination rate among the coastal zones was the highest in $\mathrm{Ba}$ risal in year 1995-1996 and the lowest in Chittagong in the year 1986-1987 and 1989-1990 (Table 3).

Considering the age $9^{\text {th }}$ year and less than $9^{\text {th }}$ year of plantations for fuel wood, the values of economic determinants were found maximum in $9^{\text {th }}$ of plantations through the coastal zones [10]. All parametric values of different economic determinants of timber were varied within the coastal divisions. Ranking on different economic determinants the optimum financial rotation for Barisal (Table 4), Chittagong (Table 5) and Patuakhali (Table 6) were as timber $16^{\text {th }}$ to $18^{\text {th }}$ year, $15^{\text {th }}$ to $16^{\text {th }}$ year and $11^{\text {th }}$ to $13^{\text {th }}$ year of plantation. However, overall results of all coastal division showed that determinants like Net Pre- sent Value (NPV), Internal Rate of Return (IRR), Land Exception Value (LE) and Equal Annual Equivalent (EAE) in terms of Le and NPV were found highest in the $11^{\text {th }}$ year of plantation (Table 7). Besides, Benefits Cost Ratio and Efficiency Index were found maximum in the $16^{\text {th }}$ year

Table 1. Average DBH and height of trees in different plantation years.

\begin{tabular}{|c|c|c|c|c|c|c|}
\hline \multirow{3}{*}{ Plantation Year } & \multicolumn{2}{|c|}{ Chittagong } & \multicolumn{2}{|c|}{ Barisal } & \multicolumn{2}{|c|}{ Patuakhali } \\
\hline & DBH & Height & DBH & Height & DBH & Height \\
\hline & $\mathrm{cm}$ & $\mathrm{m}$ & $\mathrm{cm}$ & $\mathrm{m}$ & $\mathrm{cm}$ & $\mathrm{m}$ \\
\hline $1980-1981$ & & & 29.91 & 21.53 & 25.05 & 22.29 \\
\hline 1981-1982 & 12.13 & 12.16 & 20.04 & 17.70 & 23.93 & 22.24 \\
\hline 1982-1983 & 13.13 & 11.73 & 22.96 & 20.05 & 23.89 & 21.23 \\
\hline $1983-1984$ & 12.37 & 11.03 & 25.00 & 14.30 & 22.25 & 16.82 \\
\hline 1984-1985 & 12.40 & 12.78 & & & 21.77 & 14.70 \\
\hline $1985-1986$ & 12.56 & 12.67 & 23.67 & & & \\
\hline 1986-1987 & 12.07 & 13.35 & 17.98 & 17.20 & & \\
\hline $1987-1988$ & 13.62 & 11.97 & & & & \\
\hline 1988-1989 & 9.56 & 8.10 & & & & \\
\hline $1989-1990$ & 8.66 & 7.87 & 12.16 & 13.02 & 18.98 & 18.11 \\
\hline 1990-1991 & & & 12.74 & 12.88 & 14.68 & 16.49 \\
\hline 1991-1992 & & & 13.25 & 12.57 & 13.26 & 15.09 \\
\hline $1992-1993$ & & & 12.34 & 12.19 & 10.90 & 15.27 \\
\hline \multicolumn{7}{|l|}{ 1993-1994 } \\
\hline 1994-1995 & & & & & 11.24 & 12.64 \\
\hline 1995-1996 & & & 10.37 & 8.40 & 9.51 & 9.20 \\
\hline 1996-1997 & & & 8.43 & 9.11 & & \\
\hline
\end{tabular}


Table 2. Stocking of tree and yield in different plantation years.

\begin{tabular}{|c|c|c|c|c|c|c|}
\hline \multirow[b]{2}{*}{ Plantation Year } & \multicolumn{2}{|c|}{ Chittagong } & \multicolumn{2}{|c|}{ Barisal } & \multicolumn{2}{|c|}{ Patuakhali } \\
\hline & $\begin{array}{l}\text { Stocking } \\
\text { (No/ha) }\end{array}$ & $\begin{array}{c}\text { Yield } \\
\text { (m³/ha) }\end{array}$ & $\begin{array}{l}\text { Stocking } \\
\text { (No/ha) }\end{array}$ & $\begin{array}{c}\text { Yield } \\
\text { (m³/ha) }\end{array}$ & $\begin{array}{l}\text { Stocking } \\
\text { (No/ha) }\end{array}$ & $\begin{array}{l}\text { Yield } \\
\left.\text { ( } \mathrm{m}^{3} / \mathrm{ha}\right)\end{array}$ \\
\hline 1980-1981 & & & 600 & 325.49 & 967 & 328.34 \\
\hline 1981-1982 & 1700 & 120.29 & 1167 & 276.07 & 900 & 280.40 \\
\hline 1982-1983 & 1725 & 125.96 & 1100 & 361.86 & 933 & 279.06 \\
\hline 1983-1984 & 1825 & 116.28 & 1500 & 441.57 & 1167 & 281.64 \\
\hline 1984-1985 & 1950 & 132.54 & & & 967 & 195.46 \\
\hline \multicolumn{7}{|l|}{ 1985-1986 } \\
\hline 1986-1987 & 2767 & 209.40 & 1733 & 325.80 & & \\
\hline 1988-1989 & 2550 & 89.70 & & & & \\
\hline 1989-1990 & 2900 & 80.27 & 2067 & 173.45 & 1167 & 221.11 \\
\hline 1990-1991 & & & 2167 & 188.11 & 1500 & 167.57 \\
\hline 1991-1992 & & & 1933 & 183.67 & 2167 & 208.72 \\
\hline 1992-1993 & & & 1900 & 139.37 & 2233 & 141.70 \\
\hline 1993-1994 & 2980 & 81.43 & 1930 & 140.30 & 2156 & 141.10 \\
\hline 1994-1995 & & & & & 2067 & 128.36 \\
\hline 1995-1996 & & & 2033 & 79.54 & 2433 & 89.44 \\
\hline 1996-1997 & & & 2067 & 61.64 & & \\
\hline
\end{tabular}

Table 3. Elimination of percentage of trees in different plantation years.

\begin{tabular}{|c|c|c|c|}
\hline Plantation Year & Chittagong & Barisal & Patuakhali \\
\hline $1980-1981$ & & $10 \%$ & $10 \%$ \\
\hline 1981-1982 & $5 \%$ & $8 \%$ & $9 \%$ \\
\hline $1982-1983$ & $5 \%$ & $9 \%$ & $9 \%$ \\
\hline $1983-1984$ & $6 \%$ & $24 \%$ & $9 \%$ \\
\hline 1984-1985 & $6 \%$ & & $10 \%$ \\
\hline $1985-1986$ & $5 \%$ & $25 \%$ & $10 \%$ \\
\hline 1986-1987 & $3 \%$ & $32 \%$ & \\
\hline $1987-1988$ & $4 \%$ & & \\
\hline 1988-1989 & $4 \%$ & & \\
\hline $1989-1990$ & $3 \%$ & $18 \%$ & $10 \%$ \\
\hline 1990-1991 & & $6 \%$ & $8 \%$ \\
\hline 1991-1992 & & $7 \%$ & $6 \%$ \\
\hline 1992-1993 & & $3 \%$ & $6 \%$ \\
\hline 1993-1994 & & $5 \%$ & \\
\hline 1994-1995 & & $4 \%$ & $9 \%$ \\
\hline $1995-1996$ & & $50 \%$ & $8 \%$ \\
\hline 1996-1997 & & $50 \%$ & \\
\hline
\end{tabular}

Note: Blank space indicates trees harvested or not plated at all. 
plantation (Table 7). So the optimum rotation can be chosen within the age of $14^{\text {th }}$ to $16^{\text {th }}$ year of plantation considering other intangible benefit than benefit of plantation production. On the other hand, it is observed in Table 4, Table 5 and Table 6 that there is no such difference in the values of NPV, IRR, B/C ratio, EI, Le, $\mathrm{EAE}_{\mathrm{Le}}$ and $\mathrm{EAE}_{\mathrm{NPV}}$ among $11^{\text {th }}$ year to $22^{\text {nd }}$ year of plantations in all Coastal Afforestation Divisions expect a few exceptions. All these determinants show acceptable results indicating profitability of keora plantations. A few years plantations from $5^{\text {th }}$ year to $10^{\text {th }}$ year indicated small values in comparison with $11^{\text {th }}$ year to $22^{\text {nd }}$ year plantations in Barisal and Patuakhali Coastal Afforestation Divisions. The small values of the determinants are due to young aged plantation [11]. These plantations are now also profitable and may be more profitable after $10^{\text {th }}$ year. However, overall results of the determinants show the same indication that coastal plantation of keora is profitable.

Table 4. Results of economic determinants in different ages in Barisal.

\begin{tabular}{|c|c|c|c|c|c|c|c|}
\hline Age & NPV & IRR & $\mathrm{B} / \mathrm{C}$ & EI & Le & $\mathrm{EAE}_{\mathrm{Le}}$ & $\mathrm{EAE}_{\mathrm{NP}}$ \\
\hline 22 & 67770 & $36 \%$ & 2.78 & 1.78 & 9491 & 1082 & 7726 \\
\hline 21 & 62005 & $34 \%$ & 2.68 & 1.68 & 9688 & 1120 & 7169 \\
\hline 20 & 91429 & $39 \%$ & 2.79 & 1.79 & 15963 & 1875 & 10739 \\
\hline 19 & 122328 & $42 \%$ & 2.77 & 1.77 & 23911 & 2859 & 14624 \\
\hline 18 & 120835 & $44 \%$ & 2.76 & 1.76 & 28554 & 3551 & 14939 \\
\hline 17 & 107574 & $42 \%$ & 2.60 & 1.60 & 29640 & 3831 & 13721 \\
\hline 16 & 119341 & $46 \%$ & 2.74 & 1.74 & 33197 & 4243 & 15254 \\
\hline 15 & 94313 & $40 \%$ & 2.45 & 1.45 & 30725 & 4110 & 12504 \\
\hline 14 & 93305 & $39 \%$ & 2.42 & 1.42 & 36943 & 5222 & 13025 \\
\hline 13 & 69285 & $33 \%$ & 2.15 & 1.15 & 28253 & 3977 & 9754 \\
\hline 12 & 92297 & $38 \%$ & 2.39 & 1.39 & 43161 & 6334 & 13546 \\
\hline 11 & 107157 & $61 \%$ & 2.69 & 1.69 & 57825 & 8903 & 16498 \\
\hline 10 & 88668 & $62 \%$ & 2.65 & 1.65 & 55635 & 9054 & 14430 \\
\hline 9 & 44852 & $38 \%$ & 1.89 & 0.89 & 28363 & 4639 & 7321 \\
\hline 8 & 22943 & $27 \%$ & 1.52 & 0.52 & 14727 & 2432 & 3767 \\
\hline 7 & 1035 & $15 \%$ & 1.14 & 0.14 & 1091 & 224 & 213 \\
\hline 6 & 384 & $13 \%$ & 1.06 & 0.06 & 498 & 114 & 88 \\
\hline 5 & 11989 & $21 \%$ & 1.33 & 0.33 & 7909 & 1328 & 1990 \\
\hline
\end{tabular}

Table 5. Results of economic determinants in different ages in Chittagong.

\begin{tabular}{|c|c|c|c|c|c|c|c|}
\hline Age & NPV & IRR & $\mathrm{B} / \mathrm{C}$ & EI & Le & $\mathrm{EAE}_{\mathrm{Le}}$ & $\mathrm{EAE}_{\mathrm{NPV}}$ \\
\hline 21 & 35277 & $30 \%$ & 2.60 & 1.60 & 5512 & 637 & 4079 \\
\hline 20 & 41072 & $32 \%$ & 2.64 & 1.64 & 7171 & 842 & 4824 \\
\hline 19 & 41603 & $34 \%$ & 2.63 & 1.63 & 8132 & 972 & 4974 \\
\hline 18 & 52876 & $37 \%$ & 2.68 & 1.68 & 11596 & 1414 & 6447 \\
\hline 17 & 77664 & $42 \%$ & 2.71 & 1.71 & 20047 & 2528 & 9771 \\
\hline 16 & 102452 & $47 \%$ & 2.75 & 1.75 & 28499 & 3643 & 13095 \\
\hline 15 & 100074 & $53 \%$ & 3.05 & 1.95 & 27837 & 3558 & 12791 \\
\hline 14 & 51754 & $45 \%$ & 2.64 & 1.64 & 18500 & 2511 & 7025 \\
\hline
\end{tabular}


Table 6. Results of economic determinants in different ages in Patuakhali.

\begin{tabular}{|c|c|c|c|c|c|c|c|}
\hline Age & NPV & IRR & $\mathrm{B} / \mathrm{C}$ & EI & Le & $\mathrm{EAE}_{\mathrm{Le}}$ & $\mathrm{EAE}_{\mathrm{NPV}}$ \\
\hline 22 & 79660 & $39 \%$ & 2.78 & 1.78 & 13908 & 1634 & 9357 \\
\hline 19 & 76496 & $34 \%$ & 2.72 & 1.72 & 10713 & 1221 & 8721 \\
\hline 21 & 72009 & $36 \%$ & 2.73 & 1.73 & 11251 & 1301 & 8326 \\
\hline 20 & 87942 & $40 \%$ & 2.75 & 1.75 & 17190 & 2055 & 10513 \\
\hline 18 & 66770 & $39 \%$ & 2.73 & 1.73 & 14643 & 1785 & 8141 \\
\hline 17 & 94256 & $47 \%$ & 2.73 & 1.73 & 32144 & 4387 & 12640 \\
\hline 16 & 97652 & $54 \%$ & 2.72 & 1.72 & 39699 & 5661 & 13735 \\
\hline 15 & 118014 & $59 \%$ & 2.71 & 1.71 & 57185 & 8579 & 17520 \\
\hline 14 & 109634 & $61 \%$ & 2.66 & 1.66 & 60359 & 9459 & 16999 \\
\hline 13 & 121741 & $55 \%$ & 2.73 & 1.73 & 49644 & 6989 & 17138 \\
\hline 12 & 101049 & $60 \%$ & 2.71 & 1.71 & 47254 & 6935 & 14830 \\
\hline 11 & 138376 & $65 \%$ & 2.71 & 1.71 & 74672 & 11497 & 21305 \\
\hline 10 & 101254 & $63 \%$ & 2.62 & 1.62 & 63532 & 10340 & 16479 \\
\hline 9 & 52494 & $42 \%$ & 1.98 & 0.98 & 33399 & 5476 & 8589 \\
\hline 8 & 3734 & $20 \%$ & 1.35 & 0.35 & 3265 & 612 & 700 \\
\hline 7 & 957 & $14 \%$ & 1.10 & 0.10 & 1008 & 207 & 197 \\
\hline
\end{tabular}

Table 7. Results of economic determinants in different ages of plantations in costal zone.

\begin{tabular}{|c|c|c|c|c|c|c|c|}
\hline Year & NPV & IRR & $\mathrm{B} / \mathrm{C}$ & EI & Le & $\mathrm{EAE}_{\mathrm{Le}}$ & $\mathrm{EAE}_{\mathrm{NPV}}$ \\
\hline 22 & 59848 & $34 \%$ & 2.70 & 1.70 & 8572 & 980 & 6842 \\
\hline 21 & 58362 & $34 \%$ & 2.68 & 1.68 & 9370 & 1088 & 6773 \\
\hline 20 & 70897 & $37 \%$ & 2.73 & 1.73 & 12668 & 1494 & 8357 \\
\hline 19 & 87715 & $39 \%$ & 2.73 & 1.73 & 17566 & 2109 & 10528 \\
\hline 18 & 88473 & $42 \%$ & 2.73 & 1.73 & 21081 & 2621 & 10950 \\
\hline 17 & 101427 & $45 \%$ & 2.70 & 1.70 & 30094 & 3953 & 13152 \\
\hline 16 & 105689 & $51 \%$ & 2.84 & 1.80 & 33578 & 4487 & 13927 \\
\hline 15 & 88027 & $48 \%$ & 2.60 & 1.60 & 35470 & 5067 & 12350 \\
\hline 14 & 101470 & $50 \%$ & 2.54 & 1.54 & 48651 & 7341 & 15012 \\
\hline 13 & 95513 & $44 \%$ & 2.44 & 1.44 & 38949 & 5483 & 13446 \\
\hline 12 & 96673 & $49 \%$ & 2.55 & 1.55 & 45208 & 6635 & 14188 \\
\hline 11 & 122767 & $63 \%$ & 2.70 & 1.70 & 66249 & 10200 & 18902 \\
\hline 10 & 94961 & $63 \%$ & 2.63 & 1.63 & 59584 & 9697 & 15454 \\
\hline 9 & 48673 & $40 \%$ & 1.94 & 0.94 & 30881 & 5058 & 7955 \\
\hline 8 & 13339 & $24 \%$ & 1.43 & 0.43 & 8996 & 1522 & 2233 \\
\hline 7 & 996 & $14 \%$ & 1.12 & 0.12 & 1050 & 216 & 205 \\
\hline 6 & 384 & $13 \%$ & 1.06 & 0.06 & 498 & 114 & 88 \\
\hline 5 & 11989 & $21 \%$ & 1.33 & 0.33 & 7909 & 1328 & 1990 \\
\hline
\end{tabular}




\section{Acknowledgements}

The authors would like to express their appreciation to the Editor and an anonymous referee for constructive and valuable comments that considerably improved the quality and the appearance of the manuscript.

\section{REFERENCES}

[1] S. Das and N. A. Siddiqui, "The mangrove and mangrove forest of Bangladesh,” Bulletin No. 2, Mangrove Silviculture Division, Bangladesh Forest Resrarch Institute, Chittagong, 1985.

[2] N. A. Siddiqui and M. A. S. Khan, "Growth Performance of Mangrove Trees along Coastal Belt of Bangladesh," Mangrove Ecosystem Occasional Paper, Thomson Press, Delhi, 2000.

[3] M. W. Baksha, "Report on the Pest Attack on Keora Plantation at Char Kashem under Coastal Afforestation Division,” Forest Protection Division, Bangladesh Forest Research Institute, Chittagong, 1983.

[4] S. S. Islam, "Infestation of Stem Borer in Keora Plantation in Bangladesh," The Journal of Forest Science, Vol. 18, No. 1-2, 1989.

[5] R. Drigo, "The Maturing Mangrove Plantation of the
Coastal Afforestation Project,” Assistance to the Forestry Sector, FAO/UNDP Project BGD/85/085, 1997.

[6] M. V. Dalmacio and K. M. Bajracharya, "Back to Office Report from a Tour of Noakhali Coastal Afforestation Division on 6-12 March,” FAO/UNDP Project Report BGD/ 85/085, 1989

[7] N. A. Siddiqi, "Growth, Natural Thinning and Wood Production in a Keora (Sonneratia apetala) Stand,” Bano Biggyan Patrika, Vol. 17, 1988, pp. 91-93.

[8] M. S. Iftekhar and M. R. Islam, "Degeneration of Bangladesh Sundarbans Mangroves: A Management Issue," Journal of Social Science, Vol. 6, 2004, pp. 123-135.

[9] M. R. Islam, "Where Land Meets the Sea: A Profile of the Coastal Zone of Bangladesh,” The University Press Limited, Dhaka, 2004.

[10] J. G. Kairo, F. Dahdouh-Guebas, J. Bosire and N. Koedam, "Restoration and Management of Mangrove Systems-A Lesson for and from the East African Region," South African Journal of Botany, Vol. 67, 2008, pp. 383389.

[11] N. A. Khan, J. K. Choudhury and K. S. Huda, "Forestry Sector Review Report,” Bangladesh Forest Department, Ministry of Environment and Forest, Dhaka, 2009. 